\title{
Influence of various levels of L-asparaginase II purification on the cytotoxicity, DNA level, and apoptosis in Hep-2 cells
}

\section{تأثيرالمستويات المختلفة من التنقية لأنزيم L-asparaginase II في السمية الخلوية ،

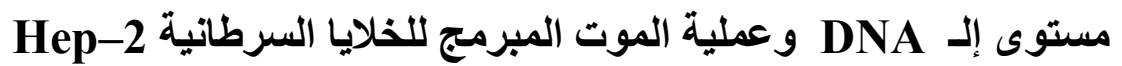

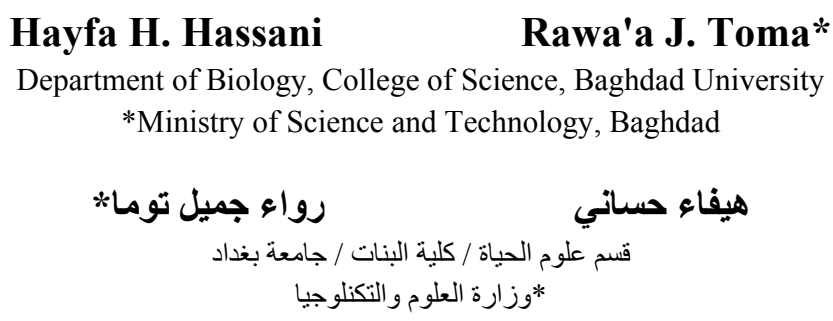

\begin{abstract}
$\widetilde{0}$ he genetic effects of several concentrations of L-Asparaginase II (ASNase II), produced by Proteus vulgaris strain Pv.U92, at various levels of purification (ultrasonication, precipitation, ion-exchange chromatography and gel filtration chromatography) on cancer cells line of Hep-2 were studied. This bacterial enzyme with concentration $4 \mathrm{U} / \mathrm{ml}$ at gel filtration level was revealed a putative cytotoxicity against cancer cells in comparison with other concentrations and steps of purification were used in this work. Moreover, 4 $\mathrm{U} / \mathrm{ml}$ of ASNase II at gel purification level has a distinguished role on arrest cancer cells division of Hep-2; it was reduced the content of DNA at each phase of cancer cell cycle particularly at $G_{2} / M$ phase, the level of DNA was $3 \%$. On the other hand, the partial purified enzyme, L-ASNase II, was induced apoptosis by both levels of purification ion-exchange and gel filtration, the apoptotic fractionation was 0.86 and 0.7 respectively.
\end{abstract}

المستخلص

درست التأثيرات الوراثية لتراكيز مختلفة من أنزيم ASNase II) L-Asparaginase II ) المنتج من

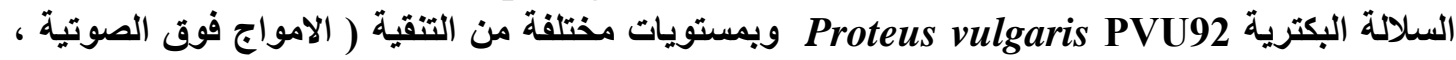

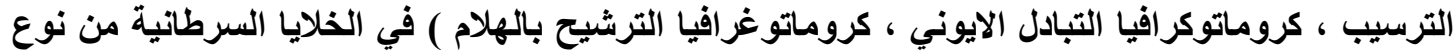
Hep-2

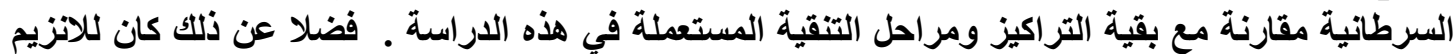

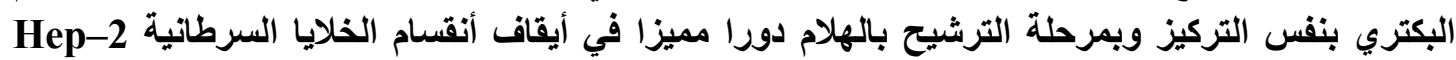

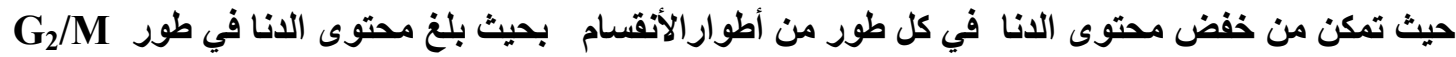

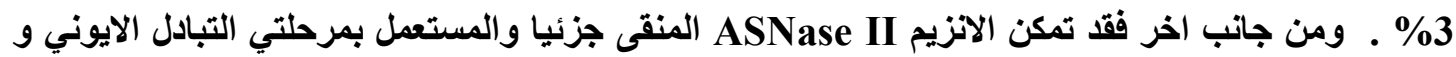

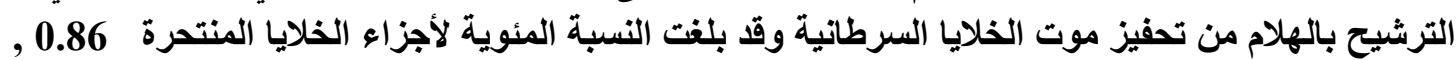

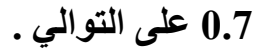

\section{Introduction}

L-asparaginase (ASNase) is L-asparagine amido hydrolase enzyme, the systematic code is E.C. 3.5.1.1, it belongs to an amidase group that produces aspartic acid and ammonia by asparagines hydrolysis [1].

L-asparaginase II(ASNase) presents in almost Enterobacteriaceae in two types: ASNase I and ASNase II. ASNase I have low affinitv and located at cvtonlasm. while Keywords: bacterial ASNase II, purification, cytotoxicity, apoptosis, cell cycle, MTT assay 
ASNase II has high affinity and located at periplasm. Only ASNase II has antilymphoma activity [2].

Normal human cells are able to make L-asparagine they need internally by Lasparagine synthetase (ASNase), in contrast neoplastic cells lacking adequate level of ASNase because it's gene is highly methylated [3], therefore tumor cells require huge amounts of L-asparagine to keep up their rapid malignant growth; it means they use both L-asparagine from diet as well what they can make themselves to satisfy their large L-asparagine demanded [4].

In present study, an attempt to evaluate the cytotoxicity and apoptosis of ASNase II at different steps of purification against cancer cell line Hep-2 was done.

\section{Materials and Methods}

\section{L-Asparaginase synthetase II (ASNase II)}

ASNase II at various steps of purification (ultrsonication, precipitation, DEAEcellulose exchange chromatography, and sephacryl S-300) was produced by strain of Proteus vulgaiis Pv.U92 that kindly provided by [5].

\section{Cell culture}

Human epidermoid larynx carcinoma (Hep-2) cell line at passage 323, kindly provided by Iraqi Center for Cancer and Medical Genetics Research (ICCMGR), was cultured in RPMI medium 1640 containing $2 \mathrm{mM}$ L-glutamine, and supplemented with $10 \%$ heat-inactivated fetal bovine serum (FBS), $100 \mathrm{unit} / \mathrm{ml}$ penicillin, and 100 $\mathrm{mg} / \mathrm{ml}$ streptomycin. The cells were cultured at $37^{\circ} \mathrm{C}$ in a humidified incubator with $5 \% \mathrm{CO}_{2}[6]$.

\section{Examination of cytotoxicity of ASNase II}

MTT [3-(4, 5-dimethylthiazol-2-yl-2, 5-diphenyltetrazolium bromide)] assay was conducted as previously described [7]. In briefly, $2 \times 10^{5}$ cells per well were seeded onto 96-well culture plates in $200 \mu \mathrm{l}$ RPMI 1640 medium and incubated for $24 \mathrm{~h}$. After incubation period, the cells were washed with same medium and then replaced with fresh medium containing different concentrations of ASNase II $(0.25,0.5,1,2$, 4) $U / \mathrm{ml}$, each concentration had three repeated wells. The plates were incubated at $37^{\circ} \mathrm{C}$ for $(3,24,48) \mathrm{hr}$. The non-treated cells were represented the negative control. After incubation period, $10 \mu \mathrm{l}$ of $5 \mathrm{mg} / \mathrm{ml}$ MTT solution was added to the culture and incubated for $4 \mathrm{~h}$ at $37^{\circ} \mathrm{C}$. Subsequently, medium was sucked out and $100 \mu \mathrm{l}$ of dimethylsulfoxide (DMSO) was added to dissolve the violet crystal and the MTT formazan was spectrophotometrically measured at $570 \mathrm{~nm}$. The percentage of inhibition rate was estimated [8].

\section{Cell cycle analysis of treated Hep-2}

Approximately $1.5 \times 10^{6}$ cell $/ \mathrm{ml}$ of Hep- 2 was treated with $4 \mathrm{U} / \mathrm{ml}$ of ASNase II at different levels of purification and incubated for $72 \mathrm{~h}$ at $37^{\circ} \mathrm{C}$. Subsequently, cells were collected by centrifugation (500xg for $5 \mathrm{~min}$.) and treated with $10 \mu \mathrm{M}$ of $\mathrm{BrdU}$ for $30 \mathrm{~min}$. at $37^{\circ} \mathrm{C}$; cells were washed with phosphate buffer solution (PBS) and resuspended with $1 \mathrm{ml}$ of Borax buffer. The step of washing was repeated twice. Thereafter, cells were re-suspended in $200 \mu \mathrm{l}$ of PBS and labeled with $4 \mu \mathrm{l}$ of goatanti-mouse FITC-conjugated antibody, incubated for $30 \mathrm{~min}$. at $4^{\circ} \mathrm{C}$ in the dark. Cells 
were resuspended with $200 \mu \mathrm{l}$ of Propidium Iodide (PI) and analyzed with flow cytometer at $488 \mathrm{~nm}$ Argon laser [9].

\section{Measurement of apoptotic cell fractionation}

A suspension of $1.5 \times 10^{6} \mathrm{cell} / \mathrm{ml}$ of Hep- 2 was plated in 96 -well microplate, treated with $4 \mathrm{U} / \mathrm{ml}$ of ASNase II at various levels of purification and then incubated at $37^{\circ} \mathrm{C}$ for $3 \mathrm{~h}$. After incubation, the adherent cells were treated with trypsin to remove them from the plate surface; cells (the floating and detached cells) were collected by centrifugation at $1500 \mathrm{rpm}$ for $10 \mathrm{~min}$. and washed with PBS. The pellets were resuspended in $4 \mathrm{ml}$ of $3.7 \%$ paraformaldehyde and left for $20 \mathrm{~min}$. Then, the cells were centrifuged at $1500 \mathrm{rpm}$ for $10 \mathrm{~min}$., washed twice with PBS, re-suspended in 20 $\mathrm{ml}$ PBS, deposited it on polylysine-coated cover slips, and left to adhere on coverslips for $30 \mathrm{~min}$ at $25^{\circ} \mathrm{C}$ followed by washing twice with PBS. Thereafter, $0.1 \%$ Triton $\mathrm{X}-$ 100 was gently added, left for $5 \mathrm{~min}$. at $25^{\circ} \mathrm{C}$, then rinsed three times with PBS. The cover slips were incubated with Hoechst $33258(1 \mathrm{mg} / \mathrm{ml})$ for $30 \mathrm{~min}$ at $37^{\circ} \mathrm{C}$. The cover slips were rinsed with PBS and amount on slides with glycerol-PBS (1:1). The apoptotic cell fraction was calculated by taking the ratio of floating cells: total cell number [10].

\section{Statistical analysis}

Experimental data were analyzed using ANOVA at probability level $P<0.05$.

\section{Results and Discussion}

Cytotoxicity of ASNase II at different concentrations and various levels of purification on cancer cell line Hep-2:

At ultrasonication step, all concentrations of ANSase II were decreased the displayed effective inhibition rate (61.4\%) after treatment for $24 \mathrm{~h}$. Figure (1).

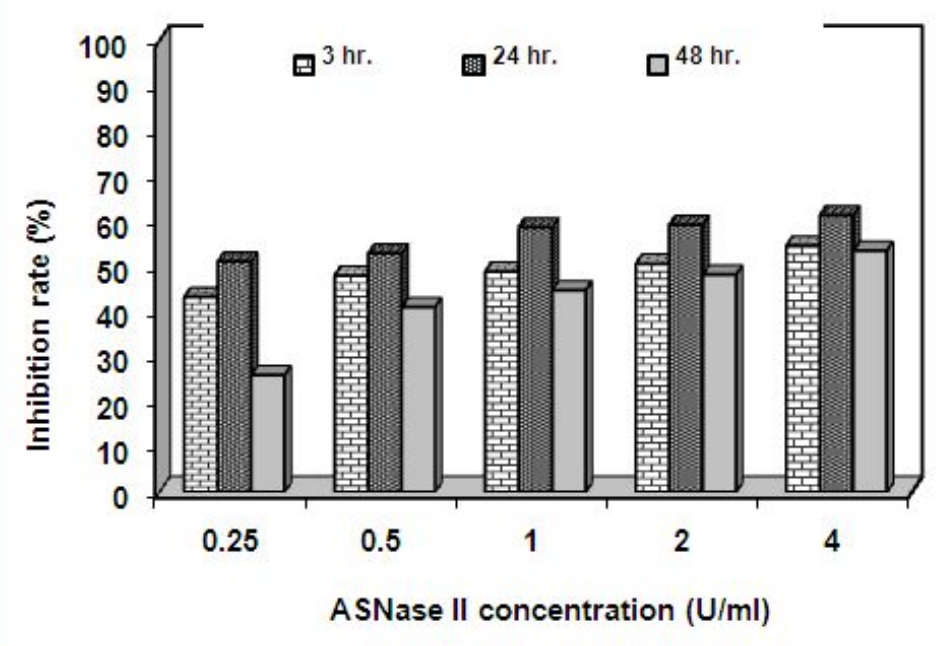

Fig (1): Cytotoxic effect of ASNase II at ultrasonication level of purification on Hep-2cell

While, the cytotoxic activity of ASNase II at precipitation step was increased gradually with increasing concentrations Figure (2). Remarkably, the concentration $4 \mathrm{U} / \mathrm{ml}$ of ASNase II was a potent inhibitor against cancer cells after $24 \mathrm{~h}$ incubation, the inhibition rate was $54.7 \%$. Whereas, ASNase II at ion exchange level (using 
DEAE-cellulose resin) of purification was significantly $(P<0.05)$ exhibited antiproliferative activity against Hep-2 cells at concentration 2 and $4 \mathrm{U} / \mathrm{ml}$ after $3 \mathrm{~h}$; the inhibition rate was $(56,57.5) \%$, respectively Figure (3).

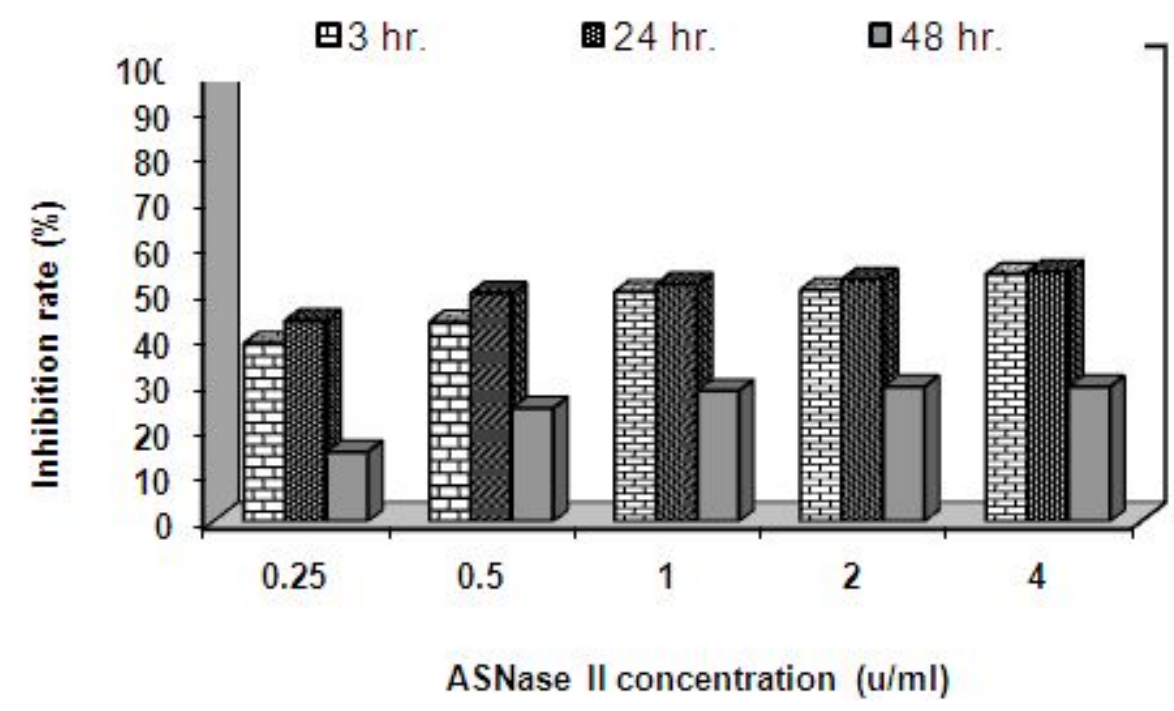

Fig (2): Cytotoxic effect of ASNase II at precipitation level of purification on Hep-2cells.

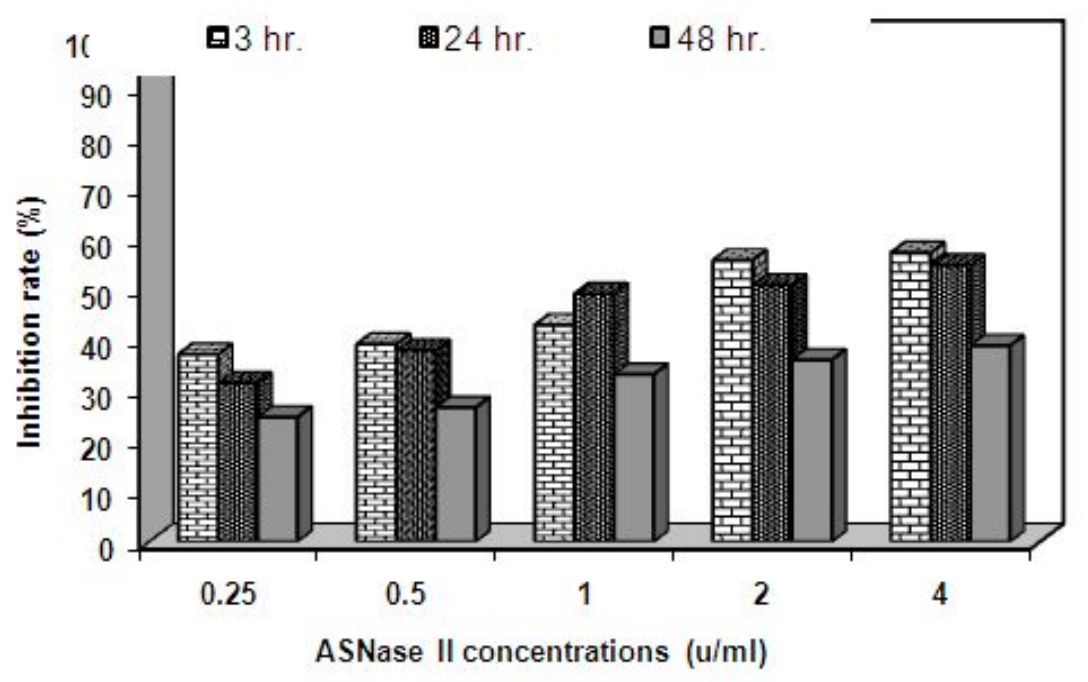

Fig (3): Cytotoxic effect of ASNase II at ion-exchange (DEAE-cellulose) level of purification on Hep-2 cells

On the other hand, ASNase II at gel filtration (using Sephacryl S-300) showed a significant $(P<0.05)$ inhibitory activity at $4 \mathrm{U} / \mathrm{ml}$ after $3 \mathrm{~h}$ from treatment; the inhibition rate was $59.8 \%$ Figure (4).

Although the inhibitory activity of ASNase II was increased after $48 \mathrm{~h}$ through increasing the concentrations of ASNase II at all purification levels used in this experiment, non- significant $(P<0.05)$ cytotoxicity were seen in comparison with other levels of purification Figure $(1,2,3,4)$. 


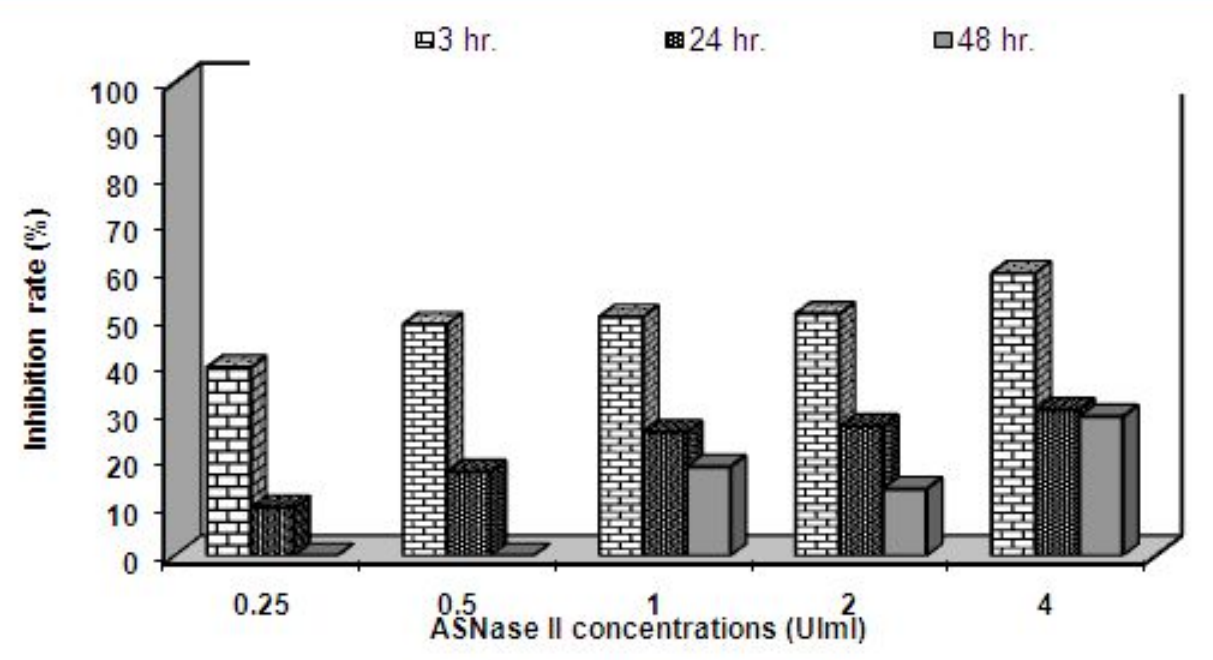

Fig (4): Cytotoxic effect of ASNase II at gel filtration (Sephacryl S-300) level of purification on Hep-2 cells.

\section{Effect of ASNase II at various levels of purification on DNA content in the cell cycle of Hep-2}

Table (1) demonstrated the inhibitory effect of $4 \mathrm{U} / \mathrm{ml}$ of ASNase II, at several levels of purification, on cell cycle and DNA content of Hep-2 cells. Remarkably, DNA content in Hep-2 cells treated with ASNase II at gel filtration step was significantly $(P<0.05)$ low at $\mathrm{G}_{0} / \mathrm{G}_{1}, \mathrm{~S}$, and $\mathrm{G}_{2} / \mathrm{M}$ phases $(90,7,3) \%$, respectively. The next level of purification that influence DNA content in Hep-2 cell cycle was ion exchange; the DNA content was $(94,1,5) \%$ at $\mathrm{G}_{0} / \mathrm{G}_{1}, \mathrm{~S}$, and $\mathrm{G}_{2} / \mathrm{M}$, respectively.

In regard to the rest purification levels (Ultrasonication and precipitation), they showed less effect in cell cycle than above levels.

Table (1): Percentage of DNA level at each phase of cell cycle of Hep-2 treated with partial purified ASNase II .

\begin{tabular}{|c|c|c|c|}
\hline \multirow[t]{2}{*}{ Purification steps of ASNase II } & \multicolumn{3}{|c|}{$\begin{array}{c}\text { Percentage of DNA content at different } \\
\text { phases of Hep-2 cell cycle }\end{array}$} \\
\hline & G0/G1 & $\mathbf{S}$ & G2/M \\
\hline Ultrasonication & 67 & 20 & 13 \\
\hline Precipitation & 75 & 15 & 10 \\
\hline Ion-exchange using DEAE-cellulose & 94 & 1 & 5 \\
\hline Gel filtration using Sephacryl S-300 & 90 & 7 & 3 \\
\hline
\end{tabular}

Effect of ASNase II at various purification levels on apoptosis of Hep-2 cell Figure (6) indicated that Hep-2 cells was very sensitive to ASNase II especially at gel filtration level of purification, the fraction of apoptotic cells was significantly high; it performed 0.86. While ANSase II at ion-exchange purification level was achieved a low apoptotic cell fractionation 0.7 with non-significant differences $(P<0.05)$ in comparison with above treatment. Whereas ultrsonication and precipitation steps of purification were revealed low efficiency in apoptosis; the fractionation of apoptotic cell was 0.5 and 0.4 , respectively. 


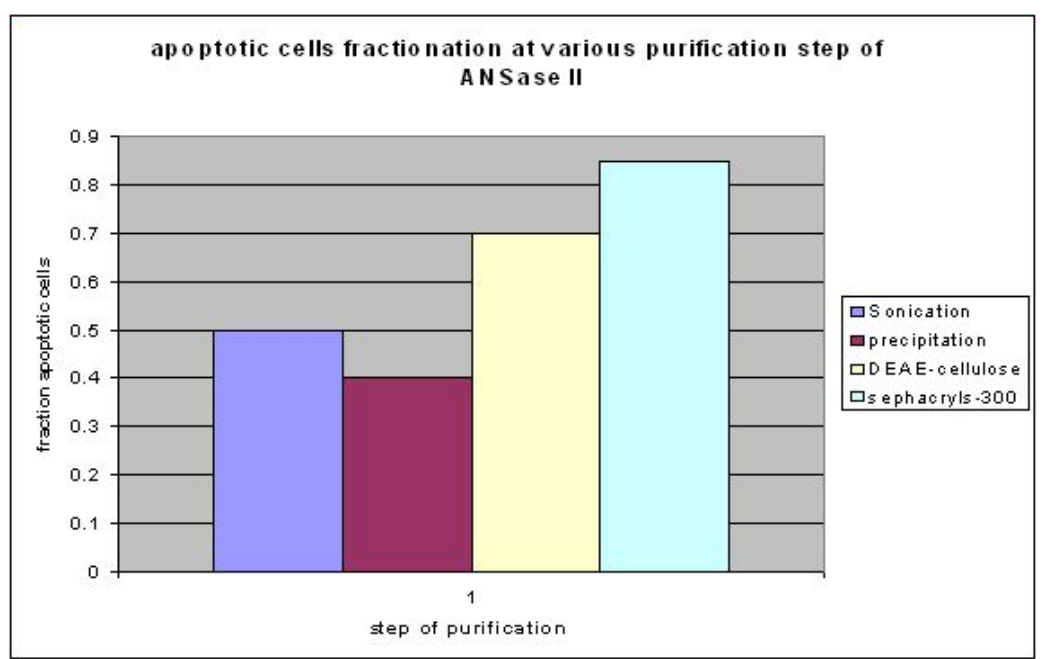

Fig (5): Apoptotic cell fractionation at various purification level of ASNase II.

\section{Discussion}

Bacterial ASNase II is an antitumor neoplastic drug used in the treatment of cancer such as lymphoblastic leukemia [11], melanosarcoma cancer [12], and lymphosarcoma [13]. In this study ASNase II showed variation in its activity against cancer cells of Hep-2 according to the level of purification. In regard to the cytotoxicity it has been indicated that ASNase II at ultrasonication level had a potent antiproliferative activity against cancer cells in comparison with other level, this may return to the presence of other compound in the extract which supports ANSase II activity. This compound is lipopolysaccharide (LPS) which its antitumor activity was proved [14]. When the cytotoxicity of ANSase II was compared with other level of purification (precipitation, ion-exchange chromatography, and gel filtration) it was appeared that it decreased with non- significance $(P<0.05)$. This may due to the elimination of compounds found in the extract [15].

On the other hand, the sequence of events leading to arrest cell cycle and death of Hep- 2 cells at $\mathrm{G}_{2} / \mathrm{M}$ phase by ASNase II is lacked. The arrest of cell cycle may retain to the decrease in the expression of key $\mathrm{G}_{2} / \mathrm{M}$-regulating proteins, including cyclin B1, cell division cycle 25B (Cdc 25B), and Cdc 25C [16]. Whereas, the ability of ASNase II, at several levels of purification, to induce apoptosis may due to upregulation of Bax, down-regulation of Bcl-2, and activation of caspases-3,-9, and -8 . Activation of caspases leads to cleavage and inactivate of cellular proteins which in turn activate mitochondrial pathway involving release of cytochrome $\mathrm{c}$, thereafter caused DNA fragmentation [17].

\section{References}

1. Capizzi RL, Poole M, Cooper MP, Richards F, Stuart JJ, Jackson DV, White DR, Spurr CL, Hopkins JO, and Muss HB. Treatment of Poor Risk Acute Leukemia with Sequential high-done ARA-C and Asparaginase .Blood 1984; 63: 649-700.

2. Campbell HA, Mashburn LT, Boyse EA, and Old LJ. Two L-Asparaginase from Escherichia coli B Their Separation, Purification, and Antitumor Activity. Biochemistry 1967; 6:721-730 
3. Ding Y, Li Z, and Broome JD. Epigenetic Changes in the Repression and Induction of Asparagine Synthetase in Human Leukemia Cell Lines. Leukemia 2005; 19: 420-426

4. Keating MJ, Holmes R, Lerner $\mathrm{S}$, and Ho DH. L-Asparaginase and PEG Asparaginase - Past, Present, and Future. Leukiema Lymphoma 1993; 10:153-157.

5. Toma RJ. Genetic Study on L-Asparaginase II Produced by Proteus spp. on cancer cell lines. MSc. Thesis, College of Science, University of Baghdad, Iraq 2008.

6. Yaseen NY. Cytogenetic Study on Human Colorectal Cancer Cell. Ph.D. Thesis, University of Sheffield Medical School, Sheffield, UK 1990.

7. Iwamoto S, Mihara K, Downing JR, Pui CH, and Campana D. Mesenchymal cells regulate the response of acute lymphoblast leukemia cells to asparaginase. J.Clin. Invest. 2007; 117: 1049-1057 .

8. Betancur-Galvis LA, Morales GE, Forero JE, and Roldan J. Cytotoxic and Antiviral Activities of Colombian Medicinal Plant Extract of Euphorbia Genus. Mem.Inst. Oswaldo Cruz. 2002; 94: 541-546.

9. Capri M, and Barbieri D. Analysis of Cell Cycle. From www.cyto.purdue.edu. Accessed April 2008.

10. Lawrence TS, Davis MA, Hough A, and Rehemtulla A . The Role of Apoptosis in 2', 2'- Difluoro-2'- deoxycytidine (Gemcitabine) - mediated Radiosensitization. Clin. Cancer Res. 2001; 7: 314-319.

11. Sanches M, Krauchenco S, and Polikarpov I. Structure, Substrate Complexation and Reaction Mechanism of Bacterial Asparaginases. Cancer Chemical Biology 2007; 1: 75-86

12. Obama K, Tara M, and Nina K. L- Asparaginase Induced Complete Remission in Epstein - Barr virus, Positive, Multidrug Resistant, Cutaneous T-cell Lymphoma. Int.J. Hematol. 1999; 69: 260-262.

13. Soares AL, Guminaraes GM , Polakiewicz B , De Moraes Pitombo RN, and Abrahao-Neto J. Effects of Polyethylene Glycol Attachment on Physicochemical and Biological Stability of E.coli L-Asparaginase. Int.J .Pharmaceutics 2002; 237: 163-170.

14. Lee $\mathrm{CH}, \mathrm{Wu} \mathrm{CL}$, and Shiau AL. Toll-Like Receptor 4 Mediates an Antitumor Host Response Induced by Salmonella choleraesusis. Clin. Cancer Res. 2008; 14: 19051912.

15. Sarquis MI, Oliveria EMM, Santos AS, and Da Costa . Production of LAsparaginase by Filamentous Fungi . Mem. Inst. Oswaldo 2004; 99: 489-492.

16. Appel IM, Den Boer ML, Meijerink AJ, Veerman AJ, Reniers NC, and Pieters R.Up- Regulation of Asparagine Synthetase Expression Is Not Linked to the Clinical Response L- Asparaginase in Pediatric Acute Lymphoblastic Leukemia. Blood 2006; 107: 4244-4249.

17. Wyllie AH. Apoptosis, Cell Death and Cell Proliferation $.3^{\text {rd }}$ ed. Edenburgh, Scotland 2006. 